\title{
URBAN FARMING SELAMA PANDEMI COVID-19 SERTA MANFAATNYA BAGI LINGKUNGAN DAN GIZI MASYARAKAT
}

\author{
Afrah $^{1^{*}, \text { Anastasia Rouli Alodia }}{ }^{2}$, Angela Olivia Sitompul ${ }^{3}$ \\ 1,2,3 Fakultas Kesehatan Masyarakat, Universitas Indonesia, Kampus Baru UI Depok, Jawa \\ Barat 16424 \\ *email: afrah91@ui.ac.id
}

Diterima : November 2021, Diterbitkan : Desember 2021

\begin{abstract}
Abstrak
Urban farming adalah suatu bentuk kegiatan komersial atau non-komersial yang berkaitan dengan produksi, distribusi dan konsumsi bahan pangan atau produk pertanian lainnya yang berlangsung di lingkungan perkotaan. Metode penelitian yang digunakan adalah penelitian kualitatif dengan pendekatan literature review. Adapun tujuan dari penelitian ini adalah untuk mengetahui bagaimana tren urban farming pada masa pandemi Covid-19 serta manfaatnya bagi gizi dan lingkungan. Pada masa pandemi Covid-19, pemerintah Indonesia menganjurkan agar masyarakat Indonesia melakukan aktivitas sehari-hari di rumah, baik itu kegiatan bekerja maupun sekolah. Dikarenakan masyarakat menetap di rumah, trend urban farming menjadi pilihan yang diminati masyarakat selama masa pandemi Covid-19. Kegiatan urban farming membawa berbagai manfaat bagi lingkungan dan gizi masyarakat. Penerapan urban farming dapat membantu menurunkan suhu di perkotaan dan menurunkan suhu pada bangunan sehingga penggunaan pendingin ruangan dapat diminimalisir. Beberapa penelitian juga menunjukkan bahwa penerapan urban farming dapat menurunkan tingkat polusi udara. Selain itu, dengan praktik urban farming, manfaat bagi aspek gizi diantaranya adalah meningkatkan ketahanan pangan dan meningkatkan status gizi masyarakat.
\end{abstract}

Kata kunci: Urban farming, lingkungan, gizi

\begin{abstract}
Urban farming is a form of commercial or non-commercial activity related to the production, distribution and consumption of food or other agricultural products that takes place in an urban environment. This research method is qualitative research with a literature review approach. The purpose of this research is to find out how the trend of urban farming during the Covid-19 pandemic is and its benefits for nutrition and the environment. During the Covid-19 pandemic, the Indonesian government recommended that Indonesians carry out daily activities at home, whether it's work or school activities. Because people stay at home, the urban farming trend is an option that people are interested in during the Covid-19 pandemic. Urban farming activities bring various benefits to the environment and community nutrition. The application of urban farming can help reduce the temperature in urban areas and reduce the temperature in buildings so that the use of air conditioning can be minimized. Several studies also show that the application of urban farming can reduce air pollution levels. In addition, with the practice of urban farming, the benefits for the nutritional aspect include increasing food security and improving the nutritional status of the community.
\end{abstract}

Keyword: Urban farming, environment, nutrition 


\section{PENDAHULUAN}

Menurut Setiawan (2002) dalam (Belinda, 2017), urban farming merupakan bentuk usaha, baik itu komersial maupun non-komersial, yang berkaitan dengan produksi, distribusi, serta konsumsi dari bahan pangan atau hasil pertanian lain yang dilakukan di lingkungan perkotaan. Kegiatan urban farming terdiri dari penanaman, panen, dan pemasaran berbagai bahan pangan yang memanfaatkan lahan yang tersedia di perkotaan.

Produk urban farming dapat berupa produk bahan pangan maupun non pangan yang dibagi menjadi jenis produk tanaman dan produk hewan. Produk tanaman dibagi menjadi dua, yaitu tanaman pangan dan tanaman non-pangan. Produk tanaman pangan yang dimaksud, yaitu sayuran, buah-buahan, obat-obatan, dan lain sebagainya. Sementara produk tanaman non pangan seperti tanaman produksi, ornamental dan pepohonan. Sedangkan produk hewan contohnya seperti sapi, kambing, ikan, dan lain sebagainya (Belinda, 2017).

Urban farming dapat dilakukan pada 2 lokasi, yakni urban farming di dalam kota (intra-urban) dan daerah pinggiran (periurban). Secara umum, usaha urban farming difokuskan untuk skala mikro (individual/keluarga) dan usaha kecilmenengah, namun masih ada yang memiliki skala besar (skala nasional atau internasional). Kegiatan urban farming meliputi kegiatan pertumbuhan, pengolahan, dan distribusi (Fauzi, Ichniarsyah and Agustin, 2016).

Menurut Setiawan (2000), urban farming umumnya dilakukan di lahan yang tak termanfaatkan atau lahan terlantar. Urban farming dapat pula dijadikan sebagai alternatif optimasi pemanfaatan tanah kota yang semakin langka. Tanahtanah yang dapat dijadikan lokasi pertanian antara lain tanah-tanah negara yang tidak dimanfaatkan; tanah-tanah marjinal di sepanjang tepi sungai, rel kereta api, di bawah jembatan, pada lereng-lereng perbukitan, di bawah jalur/jaringan listrik; median jalan maupun tanah-tanah pekarangan milik pribadi (Belinda, 2017). Luas lahan yang digunakan rata-rata seluas 5-50 $\mathrm{m}^{2}$. Komoditas yang umum diusahakan adalah tanaman yang berumur pendek seperti aneka sayuran daun dan buah, tanaman obat serta tanaman hias (Kementerian Pertanian Republik Indonesia, n.d.).

Urban farming yang sejatinya sudah ada semenjak masa Perang Dunia II, kini terus berkembang di berbagai kota di seluruh belahan dunia, tak terkecuali di Indonesia. Berkembangnya urban farming di Indonesia lebih mengacu pada kebutuhan akan Ruang Terbuka Hijau (RTH) di kotakota besar dan banyaknya lahan kosong yang tidak optimal. Sebelum trend urban farming merebak selama masa pandemi, urban farming telah menjadi programprogram yang banyak dilakukan di sejumlah kota besar, seperti kota Surabaya, Bandung dan Makassar (Ulfa dan Pertiwi, 2020).

Pandemi Covid-19 merupakan keadaan menyebarluasnya penyakit Covid19 di dunia yang disebabkan oleh infeksi virus SARS CoV-2. Penyebarannya yang masif membuat pemerintah Indonesia menganjurkan agar masyarakat Indonesia melakukan aktivitas sehari-hari di rumah, baik itu kegiatan bekerja maupun sekolah, atau yang kita kenal dengan work from home (WFH) demi menekan angka pertumbuhan kasus positif Covid-19. Keadaan seperti ini tentunya membuat waktu kita lebih banyak tersisa dibanding masa sebelum pandemi, karena kita tidak perlu memakan waktu di perjalanan pulang-pergi tempat kerja ataupun waktu untuk berbelanja karena semua bisa kita lakukan secara online. Di sela-sela waktu tersebut banyak hal bermanfaat yang dapat kita lakukan, salah satunya adalah berkebun. Menurut Shodiq (2020) dalam (Andini, Dewi, \& Marwati, 2021) tren urban farming menjadi pilihan yang diminati masyarakat selama masa pandemi Covid-19. Menurut penelitian Mc Gee, Höltge, Maercker, \& Thoma (2018) dalam 
(Andini, Dewi, \& Marwati, 2021), situasi kehidupan yang menantang bagi seseorang dapat menciptakan dampak negatif pada kesehatan dan kesejahteraan karena perasaan stress yang dimiliki. Sementara itu, penelitian lain mengungkapkan bahwa melihat tanaman hijau dapat memberikan efek positif pada kesehatan mental dan mengurangi stress (Andini et al., 2021) Maka dari itu urban farming dianggap dapat menjadi solusi bagi sebagian orang yang merasa kesehatan dan kesejahteraannya terganggu selama Covid19.

Kegiatan urban farming yang dilakukan selama masa pandemi Covid-19 tidak hanya membawa pengaruh positif bagi kesehatan mental manusia, tetapi juga membawa manfaat bagi lingkungan sekitar. Daerah perkotaan dikenal memiliki suhu yang tinggi dan memiliki tingkat polusi yang tinggi akibat kurangnya ruang terbuka hijau (US EPA, n.d.-b). Penerapan urban farming dapat membantu menurunkan suhu di perkotaan dan menurunkan suhu pada bangunan sehingga penggunaan pendingin ruangan dapat diminimalisir. Selain itu, beberapa penelitian juga menunjukkan bahwa penerapan urban farming dapat menurunkan tingkat polusi udara ( $\mathrm{Li} \&$ Yeung, 2014).

Selain itu, gangguan besar dalam rantai pasokan makanan yang disebabkan oleh pandemi Covid-19 telah memperburuk masalah kelaparan dan kekurangan gizi yang sudah ada. Tantangan utama yang diciptakan oleh pandemi Covid-19 adalah mengganggu akses ke makanan segar dan bergizi dengan harga terjangkau bagi populasi perkotaan yang besar dan terus bertambah (Lal, 2020). Dengan praktik urban farming, manfaat bagi aspek gizi diantaranya adalah meningkatkan ketahanan pangan dan meningkatkan status gizi masyarakat. Penelitian ini dilakukan untuk mengetahui tren urban farming selama pandemi Covid-19 serta mengetahui manfaat yang didapatkan melalui kegiatan urban farming dalam aspek lingkungan dan gizi masyarakat. Diharapkan dengan diadakannya penelitian ini, masyarakat menjadi lebih tertarik untuk menerapkan sistem urban farming sebagai alternatif kegiatan yang dapat dilakukan selama masa pandemi Covid-19.

\section{METODE}

Metode yang digunakan dalam penelitian ini adalah literature review yang bertujuan untuk mempertajam informasi yang telah ada dan berkontribusi untuk membentuk perspektif baru. Metode dilakukan melalui penelusuran literatur yang disesuaikan dengan topik artikel melalui portal pencarian Google, Google scholar, berbagai database jurnal seperti Elsevier, serta website resmi instansi/lembaga yang berkaitan dengan urban farming, lingkungan, serta gizi. Pencarian literatur difokuskan pada informasi yang berhubungan dengan manfaat urban farming, seperti manfaat selama masa pandemi Covid-19, manfaat terhadap lingkungan, dan manfaat untuk kebutuhan gizi. Pencarian dilakukan dengan menggunakan beberapa keyword seperti urban farming during the pandemic, urban farming impact on environment, urban agriculture, urban farming and nutrition, nutritional problem during the pandemic, dll. Total artikel jurnal yang kami gunakan berjumlah 21 artikel, website yang kami gunakan berjumlah dua website, serta satu undang-undang.

\section{HASIL DAN PEMBAHASAN}

\section{A. Urban Farming pada Masa Pandemi Covid-19}

Selama pandemi Covid-19 berlangsung, banyak keadaan yang berubah sehingga masyarakat perlu beradaptasi dengan kondisi baru ini. Jika dilihat berdasarkan dampak positifnya, kondisi pandemi Covid-19 yang mengharuskan masyarakat untuk WFH membuat masyarakat memiliki banyak waktu yang tersisa dalam satu hari. Keadaan ini dapat masyarakat manfaatkan untuk melakukan hal baru ataupun hal yang diminati. Selain dampak positif, tidak dapat dipungkiri 
bahwa kondisi pandemi Covid-19 juga memiliki dampak negatif. Kondisi hidup yang berubah selama pandemi Covid-19 merupakan sebuah situasi kehidupan yang menantang bagi sebagian orang. Menurut penelitian, situasi kehidupan yang menantang bagi seseorang dapat menciptakan dampak negatif pada kesehatan dan kesejahteraan karena perasaan stress yang dimiliki (Andini et al., 2021). Rasa stres tersebut dapat muncul ketika seseorang merasakan hal yang tidak biasa, ketika khawatir, takut, ataupun curiga terlebih ketika melihat orang lain yang memiliki tanda-tanda penderita Covid-19, melihat berita mengenai Covid19, dan ketika terdapat kerabat atau kenalan yang sakit atau bahkan meninggal karena Covid-19 (Muslim, 2020). Selain itu, pada orang-orang yang sedang menderita penyakit berat, kondisi pandemi Covid-19 ini justru semakin membuat orang-orang tersebut mudah terkena stress yang tidak tertangani. Hal ini cenderung menyebabkan depresi yang kemudian dapat memperburuk kondisi kesehatan pasien (Syahrizal, Kharisna, dan Putri, 2020).

Menurut Taylor dalam (Khoiroh, 2013) yang mengembangkan teori coping stress dari Folkman dan Lazarus, terdapat 8 macam strategi coping, salah satu diantaranya adalah lari atau penghindaran yang berarti menghindar dari permasalahan yang dialami. Strategi coping ini dapat dilakukan dengan melakukan hal baru atau hal yang disukai untuk melupakan masalah atau penyebab stress tersebut.

Jika dilihat kembali, baik dampak positif maupun negatif dari pandemi Covid19 dapat mendorong masyarakat melakukan suatu hal baru. Salah satu kegiatan yang dapat dilakukan selama pandemi baik untuk mengisi waktu kosong maupun sebagai sarana coping stress adalah melakukan urban farming. Menurut Shodiq (2020) di dalam (Andini et al., 2021), tren urban farming menjadi pilihan yang diminati masyarakat selama masa pandemi Covid-19. Hal ini terjadi karena masyarakat merasa urban farming sangat mudah dilakukan di lingkungan manapun dan dalam keadaan apapun, serta memiliki manfaat yang besar bagi diri maupun lingkungan. Dalam hal melakukan urban farming sebagai upaya coping stress, penelitian mengungkapkan bahwa melihat tanaman hijau hasil dari urban farming dapat memberikan efek positif pada kesehatan mental dan mengurangi stress (Andini et al., 2021). Maka dari itu urban farming dianggap dapat menjadi solusi bagi sebagian orang yang merasa kesehatan dan kesejahteraannya terganggu selama Covid19.

Beberapa teknik urban farming yang dapat dilakukan masyarakat Indonesia selama masa pandemi ini, yaitu hidroponik, vertikultur, aquaponik (bila memelihara ikan dan memiliki kolam ikan), rooftop garden, dan backyard garden atau menanam tumbuhan secara konvensional di lahan rumah seperti pekarangan, balkon, dek, dan lainnya. Sementara itu, beberapa jenis tanaman yang dapat ditanam dengan teknik urban farming adalah tanaman herbal (bumbu dan obat), tanaman hias, berbagai jenis sayuran seperti cabai, kubis, lobak, jagung, sawi, kacang-kacangan, umbi-umbian, dan buah-buahan. Hal penting yang perlu diperhatikan dalam pelaksanaan urban farming adalah bibit tumbuhan dan ketersediaan air yang cukup (Belinda, 2017).

\section{B. Manfaat Urban Farming bagi Lingkungan}

1. Mengurangi Urban Heat Island

Urban Heat Island adalah suatu keadaan dimana suhu di daerah perkotaan yang didominasi oleh bangunan serta memiliki sedikit ruang terbuka hijau lebih tinggi dari daerah lainnya. Hasil studi di Amerika Serikat menunjukkan bahwa perbedaan suhu pada siang hari di daerah perkotaan dan daerah terpencil dapat mencapai $1-7^{\circ} \mathrm{F}$, sedangkan perbedaan pada suhu malam hari dapat mencapai $2-5^{\circ} \mathrm{F}$. Semakin padat populasi suatu kota, 
akan semakin tinggi perbedaan suhu yang terjadi (US EPA, n.d.-b).

Perbedaan suhu yang terjadi salah satunya diakibatkan oleh kurangnya ruang terbuka hijau di daerah perkotaan. Tumbuhan dan badan air memiliki kecenderungan untuk mendinginkan suhu udara melalui transpirasi dan evaporasi. Pemilihan material yang digunakan pada infrastruktur di perkotaan, seperti material yang digunakan sebagai atap dan jalan, cenderung lebih menyerap panas matahari dibandingkan material alam seperti tumbuhan. Aktivitas manusia juga turut andil dalam peningkatan suhu udara perkotaan. Aktivitas seperti penggunaan pendingin ruangan dan penggunaan kendaraan berbahan bakar fosil dapat memancarkan panas ke lingkungan (US EPA,n.d.-b).

Salah satu cara yang dapat digunakan untuk mengurangi Urban Heat Island adalah dengan meningkatkan ruang terbuka hijau di wilayah perkotaan. Penanaman pohon dan tumbuhan lainnya dapat membantu menurunkan suhu udara dengan proses evapotranspirasi. Berdasarkan penelitian yang dilakukan oleh University of Manchester, setiap penambahan ruang terbuka hijau di perkotaan sebesar $10 \%$, suhu udara dapat turun hingga $4^{\circ} \mathrm{C}$ (Heather, 2012) Ruang terbuka hijau tidak hanya dapat dilakukan di permukaan tanah, tetapi juga pada atap bangunan dengan menerapkan green roof (US EPA, n.d.-a). Salah satu kegiatan yang dapat dilakukan adalah rooftop farming yang merupakan salah satu bentuk urban agriculture. Jenis tanaman yang dapat ditanam antara lain selada, tomat, dan terung (Harada \& Whitlow, 2020).

Berdasarkan penelitian yang dilakukan Liu (2004) dalam (Heather, 2012), suhu pada atap yang ditumbuhi tanaman sebesar $30^{\circ} \mathrm{C}$, sedangkan atap yang tidak ditumbuhi tanaman bersuhu $70^{\circ} \mathrm{C}$.

\section{Mengurangi Polusi Udara}

Polusi udara masih menjadi masalah lingkungan yang menjadi perhatian dunia. Berdasarkan sumbernya, polutan di udara dapat diklasifikasikan menjadi polutan primer dan sekunder. Polutan primer merupakan polutan yang secara langsung dilepaskan ke atmosfer, antara lain particulate matter (PM) dan karbon monoksida (CO). Polutan sekunder merupakan polutan yang terbentuk akibat reaksi dari polutan primer dan gas lain, seperti nitrogen dioksida $\left(\mathrm{NO}_{2}\right)$ dan ozon $\left(\mathrm{O}_{3}\right)$ (Susanto, 2020).

Dari berbagai macam polusi, seperti polusi udara, air, dan tanah, polusi udara menjadi penyebab kematian yang utama. Penduduk yang tinggal di wilayah dengan tingkat polusi udara yang tinggi memiliki risiko kematian prematur yang lebih tinggi dibandingkan penduduk yang tinggal di wilayah dengan tingkat polusi udara rendah. Selain itu, tingkat kematian di perkotaan akibat polusi udara terus meningkat seiring meningkatnya tingkat polusi udara (Susanto, 2020).

Salah satu cara yang dapat dilakukan untuk mengurangi polusi udara adalah dengan menanam tanaman. Tanaman memiliki kemampuan untuk membersihkan udara dengan kemampuan menyerap polutan di udara melalui stomata yang ada pada daun. Daun pada tanaman juga dapat menahan particulate matter (PM). Selain itu, tanaman mampu memecah senyawa organik tertentu, misalnya senyawa hidrokarbon poliaromatik, melalui jaringan tanaman dan di dalam tanah (Rowe, 2011).

Tanaman dianggap mampu 
mengurangi tingkat polusi udara, seperti penelitian yang dilakukan oleh Nowak (2006) di Amerika Serikat dalam (Rowe, 2011). Pepohonan mampu mengurangi polusi udara hingga 711.000 metrik ton per tahunnya. Namun, penanaman tanaman di kota-kota besar terhalang oleh lahan yang sempit. Salah satu cara yang dapat dilakukan untuk menyiasati masalah tersebut adalah dengan menerapkan konsep green roof.

Berdasarkan penelitian yang dilakukan oleh Yang, Yu, \& Gong (2008) di Chicago, Amerika Serikat, setiap penerapan konsep green roof sebesar satu hektar, polutan udara dapat dikurangi hingga sebanyak 86 kilogram per tahunnya. Selain itu, penelitian juga menunjukkan bahwa jika konsep green roof diterapkan di semua atap bangunan di Chicago, maka polutan udara yang dapat dihilangkan dapat mencapai 2046,89 metrik ton.

Penelitian yang dilakukan oleh Safayet, Arefin, \& Hasan (2017) di Dhaka, Bangladesh memperkirakan nilai manfaat jika menerapkan konsep rooftop farming. Beberapa jenis tanaman yang ditanam oleh penduduk di Dhaka dengan menggunakan konsep rooftop farming adalah jambu biji, lemon, cabai, tomat, dan bayam. Nilai manfaat tahunan akibat berkurangnya polutan di udara adalah sebesar $0,0521 \mathrm{US} \$ \mathrm{~m}^{2}$ untuk tanaman rumput pendek, 0,0673 US $\$ / \mathrm{m}^{2}$ untuk tanaman herba tinggi, dan $0,0839 \mathrm{US} \$ / \mathrm{m}^{2}$ untuk pohon gugur.

Penggunaan konsep rooftop farming di kota-kota besar dapat bermanfaat bagi peningkatan produksi sayur. Penelitian yang dilakukan oleh (Astee \& Kishnani, 2010) menunjukkan bahwa jika konsep rooftop farming diimplementasikan di seluruh
Singapura, produksi sayur di negara tersebut dapat meningkat hingga $700 \%$. Peningkatan produksi sayur ini dapat memenuhi 35,5\% kebutuhan sayur lokal. Dengan pemenuhan kebutuhan sayur lokal ini, impor makanan Singapura dapat dikurangi. Pengurangan impor makanan ini akan mengurangi jejak karbon hingga 9.052 ton emisi setiap tahunnya.

\section{Manfaat Urban Farming terhadap Gizi}

Pandemi Covid-19 telah memperburuk masalah kelaparan dan kekurangan gizi yang sudah ada dengan menyebabkan gangguan besar dalam rantai pasokan makanan. Salah satu gangguan tersebut adalah sulitnya akses terhadap makanan segar dan bergizi dengan harga terjangkau bagi populasi perkotaan yang besar dan terus bertambah. Gangguan ini diperburuk oleh kurangnya atau lemahnya infrastruktur dan dukungan dari kelembagaan yang ada. Terganggunya rantai pasokan makanan merupakan salah satu penyebab dari tidak tercapainya ketahanan pangan (Suharjito et al., 2016).

Dalam Undang-undang Republik Indonesia Nomor 18 Tahun 2012 Tentang Pangan, ketahanan pangan didefinisikan sebagai kondisi terpenuhinya pangan bagi negara sampai dengan perseorangan, yang dapat dilihat dari tersedianya pangan yang cukup, baik jumlah maupun mutunya, aman, beragam, bergizi, merata, dan terjangkau serta tidak bertentangan dengan agama, keyakinan, dan budaya masyarakat, untuk dapat hidup sehat, aktif, dan produktif secara berkelanjutan. Untuk mencapai ketahanan pangan, masyarakat berpenghasilan rendah seringkali mengalami kendala. Biaya makanan yang seringkali mahal dan bertentangan dengan kebutuhan biaya hidup lainnya di daerah perkotaan menyebabkan mereka kesulitan dalam memenuhi kebutuhan gizinya. Hal ini juga berhubungan dengan gizi buruk dan penyakit terkait gizi lainnya yang dialami oleh masyarakat berpenghasilan rendah 
(Santo, Palmer, \& Kim, 2016). Seperti halnya stunting, yang salah satu penyebabnya adalah kurangnya akses ke makanan bergizi (Harahap, Karjoso, \& Sugianti, 2019). Untuk mengatasi hal tersebut, dibutuhkan untuk mengadopsi sistem pangan yang lebih baik, mengurangi limbah makanan di sepanjang rantai pasokan, serta mengembangkan kemampuan masyarakat melalui berkebun di rumah dan urban farming (Lal, 2020). Rumah tangga atau masyarakat berpenghasilan rendah dapat menghindari tingginya biaya makanan dengan menanam sayuran atau bahan makanan lainnya seperti buah, umbi, dan sebagainya. Mereka juga dapat berpartisipasi dalam komunitas menanam. Salah satu komunitas menanam yang sering dijumpai adalah puskesmas dan posyandu yang menyediakan kebun mereka sendiri dan bisa ditanami oleh berbagai sayuran. Melalui partisipasi langsung pada ranah urban farming, baik memiliki kebun pribadi maupun berpartisipasi dalam komunitas menanam, rumah tangga atau masyarakat yang rawan pangan dapat terpenuhi kebutuhan asupannya dan mengurangi pengeluaran biaya untuk sayuran segar.

Menurut Gray, Guzman, Glowa, \& Drevno (2013), pelaku urban farming menghemat sekitar 3,4-7,2 juta rupiah per rumah tangga per tahun dari menanam bahan makanan di kebun rumah dan juga meningkatkan ketahanan pangan melalui peningkatan akses makanan sehat. Dengan tersedianya akses yang mudah ke sayuran dan buah-buahan segar, hal ini akan mengarah ke diet yang beragam dan seimbang sehingga kebutuhan gizi individu terpenuhi dan ketahanan pangan akan tercapai (Lal, 2020) Pelaku urban farming juga lebih mungkin untuk mengkonsumsi buah dan sayuran sesuai dengan porsi yang direkomendasikan daripada masyarakat yang tidak mempraktikkan urban farming (Santo et al., 2016). Urban farming juga dapat melengkapi ketahanan pangan rumah tangga, masyarakat, dan kota dengan jenis makanan yang hanya ada pada musim tertentu, dan jika berbagi pengetahuan mengenai urban farming terus didukung dan diberikan secara memadai, urban farming dapat meningkatkan ketahanan pangan dalam jangka panjang (Siegner, Sowerwine, \& Acey, 2018).

\section{UCAPAN TERIMA KASIH}

Kami selaku penulis ingin mengucapkan terima kasih kepada para dosen pengampu mata kuliah Penulisan Ilmiah Kelas $\mathrm{C}$ atas bimbingannya dalam penulisan artikel ini serta Fakultas Kesehatan Masyarakat Universitas Indonesia yang telah memberikan bantuan dana sehingga penulisan artikel literature review ini dapat berjalan dengan baik.

\section{KESIMPULAN}

$\begin{array}{rcc}\text { Keadaan } & \text { pandemi } & \text { Covid-19 } \\ \text { mengharuskan } & \text { masyarakat } & \text { Indonesia }\end{array}$ melakukan aktivitas sehari-hari di rumah (WFH). Waktu luang yang tersedia bagi masyarakat meningkatkan minat masyarakat untuk melakukan kegiatan berkebun/urban farming yang tentunya memiliki banyak manfaat. Stress yang dihadapi masyarakat karena harus beradaptasi dengan keadaan baru ataupun waktu luang yang dimiliki masyarakat karena WFH membuat masyarakat melakukan kegiatan urban farming sebagai sarana coping stress maupun untuk mengisi waktu luang. Pada aspek lingkungan, kegiatan urban farming dapat mengurangi urban heat island serta menurunkan polusi udara. Pada aspek gizi, kegiatan urban farming dapat meningkatkan ketahanan pangan rumah tangga/masyarakat yang rawan pangan sehingga dapat terpenuhi kebutuhan asupannya dan mengurangi pengeluaran biaya untuk sayuran atau bahan makanan segar.

\section{REFERENSI}

Andini, M., Dewi, O. C., \& Marwati, A. (2021). Urban Farming During the Pandemic and Its Effect on Everyday Life. International Journal of Built Environment and Scientific Research, 
05(1). Retrieved November 16, 2021 fromhttps://jurnal.umj.ac.id/index.php /IJBESR/article/view/8932

Astee, L. Y., \& Kishnani, N. T. (2010). Building Integrated Agriculture Utilising Rooftops for Sustainable Food Crop Cultivation in Singapore. Journal of Green Building, 5(2), 105. Retrieved from https://doi.org/https://doi.org/10.3992/ jgb.5.2.105

Belinda, N. (2017). Pengembangan Urban Farming Berdasarkan Preferensi Masyarakat Kecamatan Semampir Kota Surabaya. Surabaya.

Fauzi, A., Ichniarsyah, A. and Agustin, H. (2016). Pertanian Perkotaan: Urgensi, Peranan, dan Praktik Terbaik. Jurnal Agroteknologi, 10(1), pp.49-62.

Gray, L., Guzman, P., Glowa, K. M., \& Drevno, A. G. (2013). Can home gardens scale up into movements for social change? The role of home gardens in providing food security and community change in San Jose, California. The International Journal of Justice and Sustainability, 19(2). Retrieved November 16, 2021 from https://doi.org/10.1080/13549839.201 3.792048

Harada, Y., \& Whitlow, T. H. (2020). Urban Rooftop Agriculture: Challenges to Science and Practice. Frontiers in Sustainable Food Systems, 4, 76. Retrieved November 16, 2021 from https://doi.org/10.3389/FSUFS.2020.0 0076/BIBTEX

Harahap, E. S., Karjoso, T. K., \& Sugianti, R. (2019). Analisis Faktor Ibu Dengan Kejadian Memiliki Anak Balita Stunting Di Kota Pekanbaru. Health Care: Jurnal Kesehatan, 8(2), 1-7. Retrieved November 16, 2021 from https://doi.org/10.36763/HEALTHCA RE.V8I2.55

Heather, K. L. (2012). The Environmental Benefits of Urban Agriculture on Unused, The Environmental Benefits of Urban Agriculture on Unused,
Impermeable and Semi-Permeable Spaces in Major Cities With a Impermeable and Semi-Permeable Spaces in Major Cities With a Focus on Philadelphia, PA. Philadelphia. Retrieved from https://repository.upenn.edu/mes_caps tones

Kementerian Pertanian Republik Indonesia. (n.d.). Kementan: Urban Farming Dukung Pertumbuhan Ekonomi Indonesia.

Khoiroh, Q. (2013). Hubungan strategi coping dengan tingkat premenstrual syndrome pada Mahasiswi Fakultas Psikologi Universitas Islam Negeri Maulana Malik Ibrahim Malang. Malang.

Lal, R. (2020). Home gardening and urban agriculture for advancing food and nutritional security in response to the COVID-19 pandemic. Food Security, 12, 871-876. Retrieved from https://doi.org/10.1007/s12571-02001058-3/Published

Li, W. C., \& Yeung, K. K. A. (2014). A comprehensive study of green roof performance from environmental perspective. International Journal of Sustainable Built Environment. Elsevier B.V. Retrieved from https://doi.org/10.1016/j.ijsbe.2014.05 .001

Muslim, Moh. (2020). Manajemen Stress Pada Masa Pandemi Covid-19. ESENSI: Jurnal Manajemen Bisnis, 23(2), 192-201. Retrieved from https://ibn.e-

journal.id/index.php/ESENSI/article/v iew/205

Rowe, D. B. (2011). Green roofs as a means of pollution abatement. Environmental Pollution, 159(8-9), 2100-2110. Retrieved from https://doi.org/10.1016/j.envpol.2010. 10.029

Safayet, M., Arefin, M. F., \& Hasan, M. M. U. (2017). Present practice and future prospect of rooftop farming in Dhaka city: A step towards urban 
sustainability. Journal of Urban Management, 6(2), 56-65. Retrieved from

https://doi.org/10.1016/j.jum.2017.12. 001

Santo, R., Palmer, A., \& Kim, B. (2016). Vacant Lots to Vibrant Plots: A Review of the Benefits and Limitations of Urban Agriculture. Retrieved from Baltimore:

Siegner, A., Sowerwine, J., \& Acey, C. (2018, August 22). Does urban agriculture improve food security? Examining the nexus of food access and distribution of urban produced foods in the United States: A systematic review. Sustainability (Switzerland). MDPI. Retrieved from https://doi.org/10.3390/su10092988

Suharjito, Marimin, Machfud, Haryanto, B. and Sukardi, 2016. Identifikasi dan Evaluasi Risiko Manajemen Rantai Pasok Komoditas Jagung dengan Pendekatan Logika Fuzzy. Jurnal Manajemen dan Organisasi, 1(2), p.118.

Susanto, A. D. (2020). Air pollution and human health. Medical Journal of Indonesia, 29(1), 8-10. Retrieved November 16, 2021 from https://doi.org/10.13181/MJI.COM.20 4572

Syahrizal, T., Kharisna, D. and Putri, V., 2020. Analisis Tingkat Stress pada Pasien Hemodialisa di RSUD Arifin Achmad Provinsi Riau di Masa Pandemi Covid-19. Healthcare: Jurnal Kesehatan, 9(2).

Ulfa, T. and Pertiwi, N. (2020). Pengaruh Pengetahuan, Sikap dan Perilaku Masyarakat Tehadap Kegiatan Urban Farming. UNM Environmental Journals, 4(1), pp.31-41.

Undang-undang Republik Indonesia Nomor 18 Tahun 2012 Tentang Pangan. (n.d.).

US EPA. (n.d.-a). Heat Island Cooling Strategies. Retrieved October 10, 2021,

from https://www.epa.gov/heatislands/heatisland-cooling-strategies

US EPA. (n.d.-b). Learn About Heat Islands. Retrieved November 16, 2021, from https://www.epa.gov/heatislands/learn -about-heat-islands

Yang, J., Yu, Q., \& Gong, P. (2008). Quantifying air pollution removal by green roofs in Chicago. Atmospheric Environment, 42(31), 7266-7273. Retrieved from https://doi.org/10.1016/j.atmosenv.20 08.07.003 